\title{
Studies on Biochemical Composition of Different Parts of Berries and Wine Quality of Wine Grape Varieties (Vitis vinifera $L$.)
}

\author{
Ramhari G. Somkuwar*, Dadasaheb P. Hakale and Ajay Kumar Sharma
}

ICAR-National Research Centre for Grapes, P. B. No. 3, Manjri Farm Post, Pune-Solapur Road, Pune- 412307 (INDIA)

*Corresponding author

\section{A B S T R A C T}

\section{Keywords}

Wine grapes, Anthocyanin, Juice $\mathrm{pH}$, Sugar, Seed tannins, Berry skin, Wine quality

Article Info

Accepted:

04 February 2019

Available Online:

10 March 2019
The study was conducted on six red wine varieties (Syrah, Caladoc, Grenache Noir, Tempranillo, Cabernet Franc and Nielluccio) at the farm of ICAR-National Research Centre for Grapes, Pune. Five year old vines of these varieties were selected for the study. The grapes were harvested at about $23^{\circ}$ Brix TSS. Anthocyanins, total phenols, tannins, reducing sugar, carbohydrate and protein were quantified in different parts of berries viz.; seed, skin and pulp. Among the different varieties, TSS and acidity showed non-significant effect while highest $\mathrm{pH}$ value (3.56) was found in Tempranillo and lowest (3.42) in Cabernet Franc. However, volatile acids were maximum in Grenache Noir (0.13) and minimum in Caladoc variety (0.10). The biochemical parameters like Anthocyanin in pulp and skin varied significantly among different varieties. In wine quality parameters, variety Caladoc recorded highest $\mathrm{pH}$ and ethanol \% while Cabernet Franc, Grenache Noir, Syrah and Tempranillo showed highest volatile acids, total acids, mallic acid and glucose: fructose ratio respectively. The varieties Cabernet Franc and Syrah were found better for biochemical contents and wine quality.

\section{Introduction}

Wine is one of the most popular beverages prepared from grapes through fermentation under the controlled conditions. It comprises phenolic compounds mainly classified into flavonoids and non-flavonoids (Garrido and Borges, 2013). These compounds are considered to have antioxidant, anti-cancer and anti-inflammatory properties (Arranz et al., 2012; Casas et al., 2012) and they are also responsible for some of the sensory properties like colour, aroma, flavour, bitterness and astringency in grapes and wine (Del Rio et al., 2013).

Tannin contains condensed form of polymerized flavan-3-ols and responsible for mouth feel, body and astringency of wine (Rice et al., 2017). However, flavan-3-ols are originated from berry skin and seeds at varying concentrations depending on cultivars (Ribereau-Gayon et al., 1982). These compounds are thought to be associated with bitterness and astringency in grape seed (Romeyer et al., 1986). Tannins are 
responsible for mouth feel in wine (Manns et al., 2013). However, the consumer gives less importance to wine with poor mouth feel.

Colour is the preference of consumer for red wine as it is predisposing their recognition or denial (Gonzalez-Neves et al., 2014). The colour pigments are mainly found in berry skin with a concentration ranging from 200 to $5000 \mathrm{mg} / \mathrm{kg}$ of fresh grape (Jordao et al., 1998). Among the different biochemicals, anthocyanin and tannins are responsible for colour in red wine. It also possesses antioxidant, anti-proliferative and immune modulatory properties (Mazue et al., 2014).Consumers are more attracted towards the red wine, even though the colour is not contributor in taste or smell. Wine gets its colour mainly due to the presence of anthocyanin pigments carried from the berries (Boulton, 2001).Anthocyanin concentration in wine varies with the cultivar, region and the methods used during vinification. However, it is $\mathrm{pH}$ dependent, as the $\mathrm{pH}$ reduces the intensity of red colour becomes higher (Rice et al., 2017). Casassa et al., (2014) reported that anthocyanins develops during berry ripening (veraison) and reaches its maximum during berry maturation when the process of synthesis ends. Cultural practices followed during the season also play an important role in developing major biochemicals including anthocyanins in grape berries. The studies conducted by many researchers demonstrated that, vineyard management can be used to change the levels of compounds associated with wine quality. Guidoni et al., (2002) suggested bunch thinning changes the concentration of anthocyanins in berries.

Ethanol plays an important role in wine aroma, taste and mouth feel. The concentration of ethanol is regulated by modifying sugar content in berries or harvesting at various fruit maturity level, as it was produced from sugar during fermentation (Scott et al., 2017). During vinification process, the fermentation conditions influences contents of phenolic compounds which ultimately results in decrease in organoleptic and antioxidant properties of wine (Zhang et al., 2017). The harvesting of grape is determined by checking the sugar level, acid content, colour etc. as high sugar, lower acid and rich colour are the indicating factors of harvesting (Boulton et al., 1996).

The limited work has been carried out on quality and biochemical parameters for fresh grapes and wine under tropical condition. Considering these, the present study was carried out to evaluate red wine varieties for fruit quality and biochemical parameters of berries and wine.

\section{Materials and Methods}

The present study was conducted at the experimental farm of ICAR-National Research Centre for Grapes, Pune $\left(18^{\circ} 32^{\prime} \mathrm{N}\right.$ and $73^{\circ} 51^{\prime} \mathrm{E}$ ) during 2016-17. Five year old vines of six different red wine varieties (Syrah, Caladoc, Grenache Noir, Tempranillo, Cabernet Franc and Nielluccio) grafted onto $110-\mathrm{R}$ rootstock were selected for the study. The vines were spaced at distance of $2.66 \mathrm{~m} \mathrm{X}$ $1.33 \mathrm{~m}$ trained to mini $\mathrm{Y}$ trellis with horizontal orientation of cordon having vertical shoot position.

In an annual growth period the vines are pruned twice i.e. first pruning is done during April (foundation pruning) while the second pruning in October (forward pruning).

\section{Analysis of berry quality parameters}

At harvest, the juice was extracted from grape berries and centrifuged at $500 \mathrm{rpm}$ for 5 minutes. Total soluble solids was estimated using Oeno Foss (a FTIR based analyzer) and was expressed in ${ }^{\circ}$ Brix while juice $\mathrm{pH}$ was estimated using $\mathrm{pH}$ meter. To measure volatile acids $(\mathrm{g} / \mathrm{L})$, titration method $(0.1 \mathrm{~N}$ 
$\mathrm{NaOH}$ ) using phenolphthalein indicator was used.

\section{Biochemical estimation of grape berries}

Tannins from grape berries were determined using Folin-Denis method. Tannic acid was used as standard solution and the absorbance were recorded at $700 \mathrm{~nm}$ and was expressed in $\mathrm{mg} / \mathrm{g}$. Anthocyanin was estimated using $\mathrm{pH}$ differential method ( $\mathrm{pH} 1$ and $\mathrm{pH} 4.5$ ) and absorbance was recorded at 520 and $700 \mathrm{~nm}$. The phenols from the samples were determined using Folin-Ciocalteu method (Singleton and Rossi, 1965) using Gallic acid as standard and OD recorded at $765 \mathrm{~nm}$ and was expressed in $\mathrm{mg} / \mathrm{g}$. Reducing sugar was estimated using Dinitrosalicylic acid (DNSA) method while, total carbohydrate was determined using Anthrone method with Dglucose as the standard and concentration of both were expressed in per cent. Protein estimation was done as per Lowry et al., (1951) and the total protein content in fresh berries was expressed as Bovine Serum Albumin Fraction-V equivalent (\%).

\section{Wine preparation and analysis for quality parameters}

The wine was prepared using standard protocol. Bunches from each variety were harvested after attaining the total soluble solids of around $23^{\circ}$ Brix. The separated berries were crushed in Destemmer-cumcrusher and transferred into 20L stainless steel containers. To stop the activity of naturally occurring micro-organisms, potassium meta-bisulphite (KMS) was added (5mg/10 kg grape must). The prepared grape must was then exposed to cold shock at $5^{\circ} \mathrm{C}$ and the must was incubated with commercial yeast strain EC1118 (Saccharomyces bayanus) at $20 \mathrm{mg} / \mathrm{L}$ in the form of dry active yeast. During the fermentation period, the temperature was maintained below $22 \pm 2^{\circ} \mathrm{C}$ with cold exchanger (Frozen water container). It took 11 days and the sugar level was less than $2 \mathrm{~g} / \mathrm{L}$. Wine under each variety was separated from the skins and seeds manually. As soon as the racking and lees separation were completed, $60 \mathrm{ppm} \mathrm{SO}_{2}$ was maintained and the bottles were kept in storage at $4{ }^{\circ} \mathrm{C}$ for further analysis.

The wine quality parameters $(\mathrm{pH}$, volatile acids, total acids, ethanol, and malic acid) were recorded on a FTIR based analyser called Oeno Foss. The wine samples were drown into falcon tube and centrifuged at $500 \mathrm{rpm}$ for 5 minutes and the readings were recorded.

\section{Statistical analysis}

The experiment was conducted in Randomized Block Design with six red wine varieties as treatments replicated three times. The data recorded on various parameters was tabulated using means of each treatment and was analysed using SAS version 9.3.

\section{Results and Discussion}

\section{Quality parameters of grape berries}

The volatile acids and $\mathrm{pH}$ varied significantly among the varieties while the differences for TSS and acidity were non-significant (Table 1). The highest $\mathrm{pH}$ value (3.56) was recorded in Tempranilo followed by Niellucio (3.55), while the least was in Cabernet Franc (3.42). The variation in juice $\mathrm{pH}$ might be due to varietal difference since all the varieties were grown under the same condition and the harvesting was also done at proper sugar level. The volatile acids in grape berries were higher in Grenache Noir (0.13 g/L) while Caladoc recorded lower concentration $(0.10$ $\mathrm{g} / \mathrm{L}$ ).For good wine stability, upper limit of $\mathrm{pH}$ for red wine should be 3.5 (Morris et al., 1984). Suresh and Negi (1975) reported a pH 
range of 3.1-3.7 in thirty grape wine varieties in their must.

\section{Biochemical contents of grape berries}

Significant variation was recorded for tannin content in different berry part among the different varieties. The tannins content was higher in seed followed by skin while the concentration was less in berry pulp (Table 2). The same trend was also observed for phenol and anthocyanin content. In pulp, tannin content was higher in Cabernet Franc $(0.57 \mathrm{mg} / \mathrm{g})$ while Tempranillo recorded less tannin $(0.27 \mathrm{mg} / \mathrm{g})$.

In the grape berry skin, tannin content was higher in Syrah $(19.50 \mathrm{mg} / \mathrm{g})$ compared to lower in Cabernet Franc $(9.54 \mathrm{mg} / \mathrm{g})$. However, Cabernet Franc recorded higher tannins in seed $(43.00 \mathrm{mg} / \mathrm{g})$ as compared to the lowest in Grenache Noir $(29.54 \mathrm{mg} / \mathrm{g})$. The biochemical contents in berries are the main source of wine compounds as they determine the wine quality. Sun et al., (1999) reported remarkable share of tannins in grape seed in red wine. In contrast, Kilmister et al., (2014) reported that higher anthocyanin content in berries is directly proportional to anthocyanin in wine.

The grape berries of Tempranillo and Cabernet Franc recorded less concentration of phenol in pulp and skin $(0.24 \mathrm{mg} / \mathrm{g}$ and 8.59 $\mathrm{mg} / \mathrm{g}$ respectively) as compared to higher concentration in Cabernet Franc and Syrah $(0.51 \mathrm{mg} / \mathrm{g}$ and $17.74 \mathrm{mg} / \mathrm{g}$ respectively). The seed of Cabernet Franc was higher in phenol $(39.08 \mathrm{mg} / \mathrm{g})$ and lowest in Grenache Noir (27.01 mg/g).Phenolic compounds and sugars are the two major parameters which has influence on the rheological properties such as density and viscosity and mouth feel sensations such as astringency oiliness and pungency (Neto et al., 2015). Anthocyanin content in pulp and skin of berries in different varieties varied significantly. Berry skin recorded higher concentration of anthocyanin as compared to pulp. Syrah and Caladoc recorded higher anthocyanin in pulp and skin (33.58 $\mathrm{mg} / \mathrm{L}$ and $93.24 \mathrm{mg} / \mathrm{kg}$ respectively), while Nielluccio variety recorded lower anthocyanin in pulp $(5.64 \mathrm{mg} / \mathrm{L})$ and skin $(9.39 \mathrm{mg} / \mathrm{kg})$ among different varieties. The bunch exposure to sunlight and also period required for colour development in wine varieties plays an important role in developing anthocyanin contents in grape berries. The changes in anthocyanin content also vary with the varieties. There are many factors which influence the accumulation of anthocyanin content in grape berries of them varieties and weather condition during the berry ripening are the dominant one. Torres $e t$ al., (2016) reported that high temperature during ripening significantly declines the anthocyanin concentration in grape berries due to the inhibition of anthocyanin biosynthesis. Kilmister et al., (2014) also concluded that anthocyanin concentration might be a key component for enhancing tannin solubility and extraction into wine.

Reducing sugar content in different parts of grape berries varied significantly among the different wine grape varieties studied. It was higher in the pulp followed by seeds and skin. The same trend was followed for carbohydrate and protein content. Syrah recorded highest reducing sugar in pulp $(267.27 \mathrm{mg} / \mathrm{g})$ and skin $(127.93 \mathrm{mg} / \mathrm{g})$ while in Tempranillo, reducing sugar in seed was higher $(186.40 \mathrm{mg} / \mathrm{g})$. The variety Nielluccio recorded lowest reducing sugar in pulp $(248.27 \mathrm{mg} / \mathrm{g})$ and skin $(101.93 \mathrm{mg} / \mathrm{g})$ compared to lowest reducing sugar in seed of Caladoc variety $(168.90 \mathrm{mg} / \mathrm{g})$. The Syrah recorded higher reducing sugar in pulp (267.27 mg/g) and skin while Nielluccio variety recorded lowest $(101.93 \mathrm{mg} / \mathrm{g})$ reducing sugar among the varieties. At harvest, sugar concentration in grape berries 
is directly proportional to the concentration of alcohol in wine; hence, it is necessary to ensure the adequate amount of sugar in grape berries before harvest. Xu et al., (2015) also suggested that sugars accumulate in high levels in grape berries during ripening and control a range of vital processes such as synthesis and build-up of anthocyanins and aroma compounds. Several workers stated that even though the sugars are mainly accumulated in the pulp, the total sugar content in berry skin also rises during grape ripening and this has closed relationship with the anthocyanin biosynthesis in berries (He et al., 2010). The grape grown under tropical condition generally produces high sugar and less acid. Harbertson et al., (2013) reported that during the process of verification, the concentration of soluble sugars changes considerably from a high at harvesting, which further declines during alcoholic fermentation.

Carbohydrate content in skin varied significantly while in pulp and seed it showed non-significant effect. The variety Nielluccio recorded higher carbohydrate content in skin $(131.87 \mathrm{mg} / \mathrm{g})$ while Caladoc recorded lower concentration $(119.40 \mathrm{mg} / \mathrm{g})$. Dreier et al., (2000) reported that berry growth rate is significantly correlated with increased carbohydrate concentration and water availability (Table 3).

The protein content in different parts of berries varied significantly. Higher protein content was recorded in pulp of Tempranillo $(28.21 \mathrm{mg} / \mathrm{g})$, berry skin of Grenache Noir $(46.22 \mathrm{mg} / \mathrm{g})$ and seed of Caladoc (70.23 $\mathrm{mg} / \mathrm{g})$. The lowest protein content was recorded in pulp of Caladoc $(14.67 \mathrm{mg} / \mathrm{g})$, berry skin of Nielluccio $(24.74 \mathrm{mg} / \mathrm{g})$ and seeds of Tempranillo $(47.66 \mathrm{mg} / \mathrm{g})$. Vincenzi et al., (2013) in their studies reported that grape seed protein extract is being used as a valuable fining agent for wine. However, most of the grape seeds are treated as a waste material.

\section{Wine quality}

Significant differences were recorded among the different varieties for wine quality parameters studied (Table 4). The wine made from Cabernet Franc recorded lowest $\mathrm{pH}$ (3.40) followed by Syrah (3.42) while the variety Niellucio and Caladoc recorded higher $\mathrm{pH}$ of 3.50 each respectively. Pan et al., (2011) concluded that $\mathrm{pH}$ value regulates the degradation of glucose and fructose as lower the $\mathrm{pH}$ value, slow will be the degradation. It is also playing a modulating role in wine haze formation, which diminishes or overthrows the commercial value of wine (Lambri et al., 2013).

The concentration of volatile acid was higher in wine made from Cabernet Franc $(0.36 \mathrm{~g} / \mathrm{L})$ followed by Niellucio $(0.27 \mathrm{~g} / \mathrm{L})$ while the variety Syrah recorded least volatile acids $(0.22 \mathrm{~g} / \mathrm{L})$. Total acid was higher in Grenache Noir $(4.35 \mathrm{~g} / \mathrm{L})$ followed by Tempranilo $(4.25 \mathrm{~g} / \mathrm{L})$ and least in Caladoc $(4.15 \mathrm{~g} / \mathrm{L})$. Volatile acid plays an important role in fermentation process as it delivers information about the degree of improper fermentation processes occurring during winemaking (Mateo et al., 2014) while acids, ethanol and tannins are the primary factors that determine the wine aroma, taste and mouth feel in red wine (Scott et al., 2017).

The wine made from Caladoc variety recorded higher concentration of ethanol $(13.20 \%)$ followed by Cabernet Franc $(12.80 \%)$ while the lower quantity of ethanol was recorded in Grenache Noir (12.20\%). The concentration of ethanol (14-16\%) was considered to be a fundamental requirement for the wine quality as it is linked to sugar content of grape berries, which affect the overall flavour of wine (Meillon et al., 2010). 
However, it decreases astringency and also increases the bitterness of wine (Fontoin et al., 2008).

Malic acid concentration was higher in wine made from Syrah $(2.90 \mathrm{~g} / \mathrm{L})$ followed by Niellucio $(2.75 \mathrm{~g} / \mathrm{L})$ while it was less in Caladoc $(2.10 \mathrm{~g} / \mathrm{L})$. During the wine making process, malic acid influences fermentation. Bovo et al., (2016) reported that at high concentration of malic acid, all strains of Saccharomyces yeasts were positive that enhanced the rate of fermentation process consuming all the sugar. Van Leeuw et al., (2014) reported the variation due to influence of grape cultivar on the taste and colour of wine while Zeravik et al., (2016) reported role of regional factors for the malic acid concentration in wine.

Table.1 Grape berries biochemical composition of different wine varieties

\begin{tabular}{|l|c|c|c|c|}
\hline \multirow{2}{*}{\multicolumn{1}{c|}{ Varieties }} & \multicolumn{4}{|c|}{ Berry analysis } \\
\cline { 2 - 5 } & TSS $\left({ }^{0} \mathrm{~B}\right)$ & Acidity $(\mathrm{g} / \mathrm{L})$ & Juice $\mathrm{pH}$ & VA $(\mathrm{g} / \mathrm{L})$ \\
\hline Syrah & 22.97 & 5.53 & 3.54 & 0.12 \\
\hline Caladoc & 23.00 & 5.33 & 3.46 & 0.10 \\
\hline Grenache Noir & 22.77 & 5.53 & 3.51 & 0.13 \\
\hline Tempranillo & 23.30 & 5.57 & 3.56 & 0.11 \\
\hline Cabernet Franc & 23.70 & 5.50 & 3.42 & 0.12 \\
\hline Nielluccio & 22.90 & 5.37 & 3.55 & 0.12 \\
\hline C V \% & 2.59 & 4.64 & 1.38 & 6.16 \\
\hline LSD 5\% & 1.09 & 0.46 & 0.09 & 0.01 \\
\hline Significance & $\mathrm{NS}$ & $\mathrm{NS}$ & $*$ & $*$ \\
\hline
\end{tabular}

Table.2 Changes in biochemical parameters of grape berry in different wine varieties

\begin{tabular}{|l|c|c|c|c|c|c|c|c|}
\hline \multirow{2}{*}{ Varieties } & \multicolumn{3}{|c|}{ Tannin (mg/g) } & \multicolumn{3}{c|}{ Phenol (mg/g) } & \multicolumn{2}{c|}{ Anthocyanin } \\
\cline { 2 - 10 } & Pulp & Skin & Seed & Pulp & Skin & Seed & $\begin{array}{c}\text { Pulp } \\
\text { (mg/L) }\end{array}$ & $\begin{array}{c}\text { Skin } \\
(\mathrm{mg} / \mathrm{kg})\end{array}$ \\
\hline Syrah & 0.54 & 19.50 & 36.42 & 0.48 & 17.74 & 32.33 & 33.58 & 74.68 \\
\hline Caladoc & 0.54 & 19.09 & 31.49 & 0.48 & 17.36 & 28.81 & 23.49 & 93.24 \\
\hline Grenache Noir & 0.34 & 14.22 & 29.54 & 0.30 & 12.89 & 27.01 & 16.44 & 22.78 \\
\hline Tempranillo & 0.27 & 17.43 & 35.30 & 0.24 & 15.84 & 32.29 & 7.75 & 34.52 \\
\hline Cabernet Franc & 0.57 & 9.54 & 43.00 & 0.51 & 8.59 & 39.08 & 8.92 & 15.74 \\
\hline Nielluccio & 0.30 & 11.89 & 31.62 & 0.27 & 10.75 & 28.92 & 5.64 & 9.39 \\
\hline C V \% & 1.52 & 7.50 & 3.10 & 1.52 & 3.04 & 2.36 & 6.88 & 1.22 \\
\hline LSD 5\% & 0.01 & 2.08 & 1.95 & 0.01 & 0.77 & 1.35 & 2.00 & 0.93 \\
\hline Significance & $* *$ & $* *$ & $* *$ & $* *$ & $* *$ & $* *$ & $* *$ & $* *$ \\
\hline
\end{tabular}

${ }^{*} \mathrm{p} \leq 0.05 ; * \mathrm{*} \leq 0.001 ;$ NS- No significant differences 
Table.3 Status of biochemical parameters of grape berry in different wine varieties

\begin{tabular}{|l|c|c|c|c|c|c|c|c|c|}
\hline \multirow{2}{*}{ Varieties } & \multicolumn{3}{|c|}{ Reducing sugar $\mathbf{( m g / g )}$} & \multicolumn{2}{c|}{ Carbohydrate $(\mathbf{m g} / \mathbf{g})$} & \multicolumn{3}{c|}{ Protein $(\mathbf{m g} / \mathbf{g})$} \\
\cline { 2 - 11 } & Pulp & Skin & Seed & Pulp & Skin & Seed & Pulp & Skin & Seed \\
\hline Syrah & 267.27 & 127.93 & 179.90 & 269.25 & 130.58 & 196.13 & 19.35 & 38.56 & 64.36 \\
\hline Caladoc & 263.27 & 112.93 & 168.90 & 277.85 & 119.40 & 174.62 & 14.67 & 42.50 & 70.23 \\
\hline Grenache Noir & 259.60 & 125.60 & 180.90 & 273.55 & 127.57 & 191.83 & 27.85 & 46.22 & 52.04 \\
\hline Tempranillo & 266.27 & 109.93 & 186.40 & 290.75 & 111.66 & 187.53 & 28.21 & 37.03 & 47.66 \\
\hline Cabernet Franc & 249.27 & 114.60 & 182.40 & 273.55 & 119.83 & 183.23 & 16.04 & 32.60 & 54.65 \\
\hline Nielluccio & 248.27 & 101.93 & 180.40 & 277.85 & 131.87 & 178.92 & 15.66 & 24.74 & 47.86 \\
\hline C V \% & 1.49 & 2.01 & 1.95 & 3.57 & 1.03 & 9.25 & 3.17 & 3.32 & 2.07 \\
\hline LSD 5\% & 7.04 & 4.22 & 6.37 & 18.01 & 2.31 & 31.20 & 1.17 & 2.23 & 2.12 \\
\hline Significance & $* *$ & $* *$ & $* *$ & NS & $* *$ & NS & $* *$ & $* *$ & $* *$ \\
\hline
\end{tabular}

Table.4 Effect of different wine varieties on wine quality

\begin{tabular}{|l|c|c|c|c|c|c|}
\hline \multicolumn{1}{|c|}{ Varieties } & \multicolumn{5}{c|}{ Wine analysis } \\
\cline { 2 - 7 } & $\mathrm{pH}$ & $\mathrm{VA}(\mathrm{g} / \mathrm{L})$ & $\begin{array}{l}\text { Total acid } \\
(\mathrm{g} / \mathrm{L})\end{array}$ & Ethanol \% & $\begin{array}{l}\text { Mallic acid } \\
(\mathrm{g} / \mathrm{L})\end{array}$ & $\begin{array}{l}\text { Glucose: } \\
\text { Fructose ratio }\end{array}$ \\
\hline Syrah & 3.42 & 0.22 & 4.20 & 12.60 & 2.90 & 0.75 \\
\hline Caladoc & 3.50 & 0.23 & 4.15 & 13.20 & 2.10 & 0.80 \\
\hline Grenache Noir & 3.45 & 0.25 & 4.35 & 12.20 & 2.50 & 0.95 \\
\hline Tempranillo & 3.46 & 0.24 & 4.25 & 12.50 & 2.40 & 2.05 \\
\hline Cabernet Franc & 3.40 & 0.36 & 4.20 & 12.80 & 2.60 & 0.97 \\
\hline Nielluccio & 3.50 & 0.27 & 4.22 & 13.00 & 2.75 & 0.85 \\
\hline C V \% & 1.01 & 4.63 & 1.47 & 1.51 & 3.34 & 2.41 \\
\hline LSD 5\% & 0.06 & 0.02 & 0.11 & 0.35 & 0.15 & 0.05 \\
\hline Significance & $*$ & $* *$ & $*$ & $* *$ & $* *$ & $* *$ \\
\hline
\end{tabular}

The wine made from Tempranilo recorded extremely high concentration of glucose: fructose $(2.05 \mathrm{~g} / \mathrm{L})$ followed by Cabernet Franc $(0.97 \mathrm{~g} / \mathrm{L})$ and lowest concentration in the wine made from Syrah $(0.75 \mathrm{~g} / \mathrm{L})$. Glucose concentration strongly influences the process of verification (Bovo et al., 2016).Considering the results obtained in the present investigation, the varieties Cabernet Franc and Syrah were found better for biochemical contents and wine quality.

\section{Acknowledgment}

The authors are thankful to the Director General of Agriculture, Food Processing and
Territorial Policies of the Ministry of Agriculture and Fisheries, Government of France for providing the planting material to carry out research work on evaluation of wine varieties under Pune condition. The Director, ICAR-NRC Grapes, Pune also deserves for sincere thanks for providing the guidance and required facilities for carrying out the research.

\section{References}

Arranz, S., G. Chiva-blanch, P. Valderasmartinez, A. Medina-remon, R. M. Lamuelaraventos, and R. Estruch. (2012). Wine, beer, alcohol and 
polyphenols on cardiovascular disease and cancer. Nutrients, 4(7): 759-81.

Boulton, R. B., V. L. Singleton, L. F. Bisson, and R. E. Kunkee. (1996).Principles and practices of winemaking. Chapman \& Hall, New York.

Boulton, R. (2001). The co-pigmentation of anthocyanins and its role in the color of Red Wine: A Critical Review. Am. J. Enol. Vitic. 52:67-87.

Bovo, B., C. Nadai, C. Vendramini, W. J. F. Lemos Junior, M. Carlot, A. Skelin, A. Giacomini, and V. Corich. (2016). Aptitude of Saccharomyces yeasts to ferment unripe grapes harvested during cluster thinning for reducing alcohol content of wine. International Journal of Food Microbiology. 236: 56-64.

Casas, R., G.Chiva-blanch, M. Urpi-sarda, R. Llorach, M. Rotches-ribalta, M. Guille, and R. Estruch. (2012). Differential effects of polyphenols and alcohol of red wine on the expression of adhesion molecules and inflammatory cytokines related to atherosclerosis: A randomized clinical trial. American Journal of Clinic Nutrition. 95:326-34.

Casassa, L. F. and J. F. Harbertson. (2014). Extraction, evolution, and sensory impact of phenolic compounds during red wine maceration. Annu Rev Food Sci Technol. 5: 83-109.

Del Rio, D., A. Rodriguez-Mateos, J. P. E. Spencer, M. Tognolini, G. Borges and A. Crozier. (2013). Dietary (Poly) phenolics in human health: structures, bioavailability, and evidence of protective effects against chronic diseases. Antioxid. Redox. Sign. 18:1818-92.

Dreier, L. P., G. S. Stoll and H. P. Ruffner. (2000). Berry ripening and evapotranspiration in Vitis vinifera L. Am. J. Enol.Vit. 51: 340-45.
Fontoin, H., Saucier, C., Teissedre, P.L. and Glories, Y. (2008). Effect of $\mathrm{pH}$, ethanol and acidity on astringency and bitterness of grape seed tannin oligomers in model wine solution. Food Qual. Prefer.19(3):286-91.

Garrido, J. and F. Borges. (2013). Wine and grape polyphenols- a chemical perspective. Food Research International. 54(2): 1844-58.

Gonzalez-Neves, G., G. Favre, and G. Gil. (2014). Effect of fining on the colour and pigment composition of young red wines. Food Chemistry. 157: 385-92.

Guidoni, S., P. Allara, and A. Schubert. (2002). Effect of cluster thinning on berry skin anthocyanin composition of Vitis vinifera cv. Nebbiolo. Am. J. Enol. Vitic. 3: 2001-03.

Harbertson, J. F., C. Yuan, M. S. Mireles, R. L. Hanlin and M. O. Downey. (2013). Glucose, fructose and sucrose increase the solubility of protein-tannin complexes and at high concentration, glucose and sucrose interfere with bisulphite bleaching of wine pigments.Food Chemistry.138: 55663.

He, F., L. Mu, G. L. Yan, N. N. Liang, Q.H. Pan, J. Wang, M. J. Reeves, and C. Q. Duan. (2010).Biosynthesis of anthocyanins and their regulation in coloredgrapes. Molecules. 15: 905791.

Jordao A. M., J. M. Ricardo-da-Silva and O. Laureano. (1998). Evolution of anthocyanins during grape maturation of two varieties (Vitis vinifera L.), Castelao Frances and Touriga Francesa. Vitis. 37: 93-94.

Kilmister, R. L., M. Mazza, N. K. Baker, P. Faulkner and O. Mark. (2014). Downey A role for anthocyanin in determining wine tannin concentration in Shiraz. Food Chemistry, 152: 47582. 
Lambri, M., R., R. Dordoni, M. Giribaldi, M. R. Violetta and M. G. Giuffrida. (2013). Effect of $\mathrm{pH}$ on the protein profile and heat stability of an Italian white wine. Food Research International. 54:1781-86.

Lowry, O. H, N. J. Rosenbrough, A. L. Farr and R. J. Randall. (1951). Protein measurement with the Folin phenol reagent. J. Bio.Chem. 193: 265.

Manns, D. C., C. T.Coquard Lenerz and A. K. Mansfield. (2013). Impact of processing parameters on the phenolic profile of wines produced from hybrid red grapes marechal Foch, Corot Noir and Marquette. J. Food Sci.78: C696C702.

Mateo, E., M. J. Torija, A. Masand E. J. Bartowsky. (2014). Acetic acid bacteria isolated from grapes of South Australian vineyards. International Journal of Food Microbiology.178: 98-106.

Mazue, F., D.Delmas, G.Murillo, D.Saleiro, E. Limagne and N. Latruffe. (2014). Differential protective effects of red wine polyphenol extracts (RWEs) on colon carcinogenesis. Food and Function. 5(4): 663-70.

Meillon, S., C. Urbano, G. Guillot and P. Schlich. (2010). Acceptability of partially dealcoholized wines measuring the impact of sensory and information cues on overall liking in real life settings. Food Qual. Prefer.21 (7): 763-73.

Morris, J. R., C.A. Sims, J.E. Bourque and J.L. Oakes. (1984). Relationship of must $\mathrm{pH}$ and acidity to the level of soluble solids in six French American hybrid grapes. Vitis. 33(3):4.

Neto, F. S., M. B. de Castilhos, V. R. Telis and J. Telis-Romero. (2015). Effect of ethanol, dry extract and reducing sugars on density and viscosity of Brazilian red wines. J. Sci. Food
Agric. 95:1421-27.

Pan, W., D. Jussier, N. Terrade, R.Y. Yada and R. M. deOrduna. (2011). Kinetics of sugars, organic acids and acetaldehyde during simultaneous yeast-bacterial fermentations of white wine at different $\mathrm{pH}$ values.Food Research International. 44: 660-66.

Ribereau-Gayon, P. (1982). The Anthocyanins of grapes and wines. In anthocyanins as food colors; Markakis, P., Ed.; Academic Press, INC.: New York, NY, USA. pp. 20944.

Rice, S., J. Koziel, M. Dharmadhikari and A. Fennell. (2017). Evaluation of tannins and anthocyanins in marquette, frontenac and St. Croix Cold-Hardy Grape Cultivars. Fermentation. 3:47.

Romeyer, F. M., J. J. Macheix and J. C.Sapis. (1986). Changes and importance of oligomeric procyanidins during maturation of grape (Vitis vinifera) Seeds. Phytochemistry. 25: 219-22.

Scott, C. F., J. F. Harbertsonb and H. Heymanna. (2017). A full factorial study on the effect of tannins, acidity, and ethanol on the temporal perception of taste and mouthfeel in red wine. Food Quality and Preference, 62: 1-7.

Singleton, V.L., and J. A. Rossi. (1965). Colorimetry of total phenolics with phosphomolybdic phosphotungstic acid reagent. Am. J. Enol. Vitic. 16:144-58.

Sun, B. S., T. Pinto, M. C. Leandro, J. M. Ricardo da Silva and M. I.Spranger. (1999) Transfer of catechins and proanthocyanidins from solid parts of the grape cluster into wine. Am. J. Enol. Vitic. 50: 179-84.

Suresh, E.R and S.S. Negi. 1975. Evaluation of some grape varieties for wine quality. J. Food Science \&Techn. 12(12): 79-80. 
Torres, N., N.Goicoechea, F. Morales and M. C. Antolin. (2016). Berry quality and antioxidant properties in Vitis vinifera cv. Tempranillo as affected by clonal variability, mycorrhizal inoculation and temperature. Crop Pasture Sci. 67: 961-77.

Van Leeuw, R., C. Kevers, J. Pincemail, J. O. Defraigne and J. Dommes. (2014). Antioxidant capacity and phenolic composition of red wines from various grape varieties: Specificity of Pinot Noir. Journal of Food Composition and Analysis. 36: 40-50.

Vincenzi, S., C. Dinnella, A. Recchia, E. Monteleone, D. Gazzola and G. Pasini. (2013). Grape seed proteins: A new fining agent for astringency reduction in red wine. Australian Journal of Grape and Wine Research. 19:153-60.
Xu, W., Dubos, C. and Lepiniec, L. (2015). Transcriptional control of flavonoid biosynthesis by MYB-bHLH-WDR complexes. Trends in Plant Science.20(3): 1-10.

Zeravik, J., Z. Fohlerova, M. Milovanovic, O. Kubesa, M. Zeisbergerova, K. Lacina, A. Petrovic, Z. Glatz and R. Skladal. (2016). Various instrumental approaches for determination of organic acids in wines. Food Chemistry.194: 432-40.

Zhang, S. T., L. X. Li, Y. Cui, L. X. Luo, Y. Y. Li, P. Y. Zhou, and B. S. Sun. (2017). Preparative high-speed counter-current chromatography separation of grape seed proanthocyanidins according to degree of polymerization. Food Chem. 219: 399-407.

\section{How to cite this article:}

Ramhari G. Somkuwar, Dadasaheb P. Hakale and Ajay Kumar Sharma. 2019. Studies on Biochemical Composition of Different Parts of Berries and Wine Quality of Wine Grape Varieties (Vitis vinifera L.). Int.J.Curr.Microbiol.App.Sci. 8 (03): 155-164. doi: https://doi.org/10.20546/ijcmas.2019.803.022 